\title{
POLITIK DALAM PEMIKIRAN K.H. ABDUL HALIM (1887-1962): IDE DAN GERAKAN
}

\author{
Wawan Hernawan dan Erba Rosalina Yulianti \\ Universitas Islam Negeri Sunan Gunung Djati Bandung, Indonesia \\ Wanha99@yaho.co.id
}

\begin{abstract}
This article discusses about the Islamic political thought of KH.Abdul Halim(1911-1962). By using the historical method research, this paper found that KH.Abdul Halim's Islamic political thoughts are al-salam, santi asromo, santi lucu, intisab and ishlah al-Samaniyyah. Abdul Halim movement based on the establishment of the local institution, Madjlisoel 'Ilmi, as a member of Voorzitter Hoofdbestuur Persjarikatan Oelama and The Investigating Commitee for Prparatory Work for Independence (BPUPKI). For his dedication, the Indonesian President awarded him the title of National Hero and Star of Mahaputra Adipurna that was established with the release of Presidential Decree No.041/TK/TH.2008.
\end{abstract}

Keywords: Kyai, Hoofdbestuur, Persjarikatan Oelama, National Hero.

\begin{abstract}
Abstrak
Artikel ini membahas tentang pemikiran seorang kyai dalam bidang politik. Dengan menggunakan tahapan metode sejarah, diharapkan sejumlah fakta yang ditemukan dapat disajikan sebagaimana kejadiannya. Hasil penelitian menunjukkan bahwa pemikiran politik Abdul Halim bertolak dari pemahamannya tentang rukun Islam yang ia perluas menjadi konsep al-salam, santi asromo, dan santi lucu, yang dilanjutkan dengan intisab, dan ishlah al-samaniyyah. Basis gerakan Abdul Halim dimulai dengan mendirikan lembaga lokal Madjlisoel 'Ilmi hingga menjadi Voorzitter Hoofdbestuur Persjarikatan Oelama, anggota BPUPKI, dan anggota Konstituante. Atas kiprah dan dedikasinya, Presiden Republik Indonesia melalui Surat Keputusan Nomor 041/TK/TH. 2008, menganugerahkan Gelar Pahlawan Nasional dan Bintang Mahaputera Adipradana.
\end{abstract}

Kata Kunci: Kyai, Hoofdbestuur, Persjarikatan Oelama, Pahlawan Nasional.

\section{Pendahuluan}

Peneladanan politik oleh kader dan jama'ah Persatuan Ummat Islam (PUI) terhadap sosok Abdul Halim, belakangan dirasakan mengalami penurunan. Abdul Halim, hari ini selalu digambarkan sebagai sosok yang lebih mengedepanan sikap toleransi dan pengertian, tidak menaruh perhatian pada politik, serta hanya berfokus pada bidang pendidikan, dakwah, dan sosial. Sejumlah karyanya ${ }^{1}$ pun tidak

\footnotetext{
${ }^{1}$ Menurut Gunseikanbu, buku-buku yang berhasil disusun Abdul Halim berjumlah 9 (Sembilan) buah, yaitu: Da'watoelAmal, Tarich Islam, Neratja Hidoep, Kitab Penundjoek Bagi Sekalian Manoesia, Risalah Aafatoel Idjtimaijah wa iladjuha, Kitab Tafsir Tabarak, Kitab Tafsir Surat Ma'oen, Kitab 262
} 
lagi dijadikan rujukan politik oleh kader dan jama'ahnya. Mereka lebih senang membaca dan mendiskusikan buku-buku karya Bediuzzaman Said Nursi² (23 Maret 1960, seorang ulama terkemuka Turki) ketimbang menelaah karyakarya Abdul Halim. Namun, Persjarikatan Oelama (cikal bakal organisasi Persatuan Ummat Islam) dapat bertahan di tengah ketatnya pengawasan pemerintah Hindia Belanda yang dilanjutkan dengan pemerintah Pendudukan Jepang, menunjukkan kuatnya Abdul Halim dalam mengemas ide dan gerakan politiknya. ${ }^{3}$ Sikap politik yang dikembangkannya tentu perlu dicermati secara kontekstual dengan mempertimbangkan situasi dan kondisi politik pada masa itu. ${ }^{4}$

Beberapa penulis sebelumnya menyebutkan bahwa posisi Abdul Halim dapat disebut pelaku politik, ${ }^{5}$ karena ia bersikap aktif dalam mencapai tujuan yang diamininya. ${ }^{6}$ Terdapat dugaan, gerakan Abdul Halim adalah gerakan yang mempunyai fungsi politik, meskipun hal tersebut bukan sesuatu yang diniatkan dan disengaja

Hadis Indonesia, dan Bab al-Rizqi." Buku lainnya yang tidak dilaorkan Abdul Halim ke Guseikanbu, masing-masing: Tafsir Juz 'Amma, Economie dan Cooperatie Dalam Islam, Padoman Persjarikatan Oelama, dan Padoman Propaganda Persatoean Islam. Lihat, Gunseikanbu, Orang Indonesia Jang terkemoeka di Djawa (T.tp.: Gunseikanbu, 2604/1944), 430. Lihat pula, Jalaluddin, "Santi Asromo K.H. Abdul Halim Studi tentang Pembaharuan Pendidikan Islam di Indonesia" (Disertasi S3 yang tidak dipublikasikan, IAIN Syarif Hidayatullah Jakarta, 1990), 382.

${ }^{2}$ Sebut saja misalnya: Pertama, Bediuzzaman Said Nursi, Rahasia Kenikmatan Beribadah: Kisah dan Pesan Abadi yang Mengukuhkan Akidah dan Menggairahkan Ibadah, Terjemahan Fauzi Bahreisy (T.tp.: Zaman \& Risale Press, 2012). Kedua, Bediuzzaman Said Nursi, Risalah Kebangkitan: Pengumpulan Makhluk di Padang Mahsyar (T.tp.: Risale Press, 2014). Ketiga, Sukran Vahide, Biografi Intelektual Bediuzzaman Said Nursi: Transpormasi Dinasti Usmani Menjadi Republik Turk, (T.tp.: Risale Press, 2014).

${ }^{3}$ Ahmad Faizin Karimi, Pemikiran dan Perilaku Politik Kiai Haji Ahmad Dahlan (Gresik: MUHI Press, 2012), 14.

${ }^{4}$ Ibid.

${ }^{5}$ Lihat, Abu Sjahid Hidajat, "K.H. Abdul Halim dan Perjuangannya", Panji Masyarakat 2, no. 2 (1967): 19; Lihat pula, Karel A. Steenbrink, Beberapa Aspek tentang Islam di Indonesia Abad ke-19 (Jakarta: Bulan Bintang, 1986), 73; Bandingkan dengan Deliar Noer, Gerakan Modern Islam di Indonesia 1900-1942 (Jakarta: LP3ES, 1995), 80-81.

${ }^{6} \mathrm{Ahmad}$ Faizin Karimi, 14. olehnya. ${ }^{7}$ Dalam lingkup ke-Indonesiaan pada masanya, justru gerakan yang dilakukan Abdul Halim dipandang memadai, karena kemudian banyak memberikan kontribusi bagi tumbuhnya pola-pola gerakan yang kemudian diikuti oleh generasi sesudahnya.

Abdul Halim adalah cerminan kyai Majalengka-Jawa Barat yang bukan hanya pendiri organisasai Persatuan Ummat Islam (PUI), ${ }^{8}$ tetapi termasuk salah seorang pendiri Republik Indonesia. Peranannya tidak saja ditunjukkan pada masa pemerintah Hindia Belanda, tetapi pada masa pemerintah Pendudukan Jepang, dan setelah Indonesia merdeka. ${ }^{9}$ Ia pun dikenal telah berhasil mencetak sejumlah ulama dan tokoh yang berpengaruh.

Kajian ini memfokuskan pada penelusuran ide dan gerakan politik Abdul Halim, karena dijumpai anggapan, bahwa: pertama, ia abai terhadap urusan politik. Kedua, situasi dan kondisi politik saat itu tidak dapat disamakan dan dianalisa dengan pendekatan politik saat ini. Ketiga, keberadaan organisasi pergerakan Persjarikatan Oelama pada masa itu tetap tumbuh di tengah situasi yang serba tidak menguntungkan menunjukkan keberhasilan politik Abdul Halim dalam menjalin komunikasi, baik dengan pemerintah maupun dengan sesama organisasi pergerakan lainnya yang sama-sama tumbuh pada waktu itu. Keempat, terdapatnya kecenderungan kader dan jamaah Persatuan Ummat Islam yang hari ini terjun ke dunia politik praktis, namun gerakannya berbeda dengan apa yang telah dilakukan oleh Abdul Halim. Penelusuran ini signifikan untuk menunjukkan bahwa Abdul Halim telah merumuskan ide dan gerakan

\footnotetext{
${ }^{7}$ Ibid., 15.

${ }^{8}$ Azs, "PUI Usul BIJB Bernama Bandara KH Abdul Halim"; diperoleh dari http://www.radarcirebon.com/pui-usul-bijbbernama-bandara-kh-abdul-halim.html; internet; diakses pada 15 Oktober 2017.

${ }^{9}$ Abduh, "Masyarakat Majalengka Wajib Membumikan Nilai Kepahlawanan KH Abdul Halim"; diperoleh dari http:// majalengka.cirebontrust.com/masyarakat-majalengka-wajibmembumikan-nilai-kepahlawanan-kh-abdul-halim.html; internet; diakses pada 15 Oktober 2017.
} 
politik yang cukup jelas, serta masih relevan untuk diikuti kader dan jamaahnya hingga saat ini. Hal ini merupakan diskursus politik yang berkontribusi pada pembentukan keunikan politik kaum Muslim di Indonesia.

\section{Keluarga dan Pendidikan Abdul Halim}

Arsip resmi yang membahas tentang Abdul Halim dapat diperoleh di Arsip Nasional Republik Indonesia (ANRI). Abdul Halim mencatatkan sendiri namanya Abdul Halim (Moehammad Sjatari), lahir pada 25 Sjawal Poeasa 1304 H./176-2547 Ç di Jatiwangi-Majalengka. ${ }^{10}$ Masih dalam arsip itu, pada kolom Keterangan jang lain jang mengenai oesaha bagi oemoem, Abdul Halim menulis sebagai pembangoen dan Ketoea dari perkoempoelan "Persjarikatan Oelama Indonesia" jang sekarang diganti dengan nama "Perikatan Oemat Islam, saja sebagai Djoeroe Penasehatnja”. Keterangan dalam arsip itu ditandatangani di Santi Asromo, pada 27-122602/1942. ${ }^{11}$

Ayahnya, K.H. Iskandar ibn Abdoellah Komar ibn Noersalim, bekerja sebagai Penghulu Kewedanaan Jatiwangi. Ibunya bernama Siti Mutmainah, sebagai ibu rumah tangga biasa. ${ }^{12}$ Kuat dugaan, Halim lahir dari keluarga Muslim yang taat. Selain itu, dijumpai informasi, orang tua Halim memiliki hubungan keluarga dengan pemerintah pada waktu itu. ${ }^{13}$ Dari pernikahannya

\footnotetext{
${ }^{10}$ Lihat, Abdul Halim (Mohammad Sjatari), Pendaftaran Orang Indonesia jang Terkemoeka jang Ada di Djawa, eks Arsip Gunseikanbu Cabang I, Pegangsaan Timur 36 Jakarta. Nomor A. 205 gol. III b. Nomor berkas A. 15. 2602/1942. ANRI. Lihat pula, Gunseikanbu, Orang Indonesia Jang terkemoeka di Djawa (T.tp.: Gunseikanbu, 2604), 430; Bandingkan dengan Wawan Hernawan, Seabad Persatuan Ummat Islam (1911-2011) (Bandung: Yayasan Masyarakat Sejarawan Indonesia (YMSI) Cabang Jawa Barat dan Dewan Pimpinan Wilayah Persatuan Ummat Islam Jawa Barat bekerjasama dengan Divisi CSR Bank Jabar Banten (BJB) Pusat, 2014), 54.

${ }^{11}$ Wawan Hernawan, "Abdul Halim and His Movement (19111962): Seeking Historical Roots of Persatuan Ummat Islam (PUI) Movement", dalam Internatinal Journal of Nusantara Islam 2, no. 1 (2014): 44.

${ }^{12} \mathrm{~S}$. Wanta, KH Abdul Halim dan Pergerakannya, Seri VI (Majalengka: PB PUI Majelis Penyiaran Penerangan dan Dakwah, 1991), 1.

${ }^{13}$ Deliar Noer, 80.
}

dengan Siti Mutmainah, Iskandar dikaruniai delapan orang putra dan putri, masing-masing: 1) Iloh Mardiyah, 2) Empon Kobtiyah, 3) Empeu Sodariyah, 4) Jubaedi, 5) Iping Maesaroh, 6) Hidayat, 7) Siti Sa'diyah, dan 8) si bungsu Halim, biasa disapa sebagai panggilan sayang dalam keluarga, "otong" Sjatori. ${ }^{14}$

Iskandar wafat ketika Halim masih kecil. Sepeninggal Iskandar, tidak dijumpai informasi yang menyebutkan Siti Mutmainah bersuami lagi. Kuat dugaan, ia sendirian mengasuh dan membesarkan anak-anaknya. Meskipun demikian, dijumpai informasi, Siti Mutmainah mengasuh dan membesarkan mereka dengan dasar-dasar agama Islam yang cukup ketat. Selain itu, belum dijumpai informasi yang menyebutkan jenjang pendidikan formal para putra Siti Mutmainah, termasuk Halim. Terkait dengan hal itu, Wanta menyebutkan, Halim termasuk seorang otodidak. ${ }^{15}$ Pendapat tersebut dikuatkan oleh Jalaluddin, ${ }^{16}$ Abdul Halim tidak pernah mengikuti jenjang pendidikan formal di sekolah atau madrasah. Kondisi demikian segera dimengerti, mengingat situasi kehidupan bangsa Indonesia pada masa itu benar-benar kurang menguntungkan di segala bidang, termasuk sistem dan tata-laksana penerimaan calon siswa di sekolah Gouvernement. ${ }^{17}$

Memang terdapat informasi, sejak 1864 Sekolah Dasar Bumiputera telah dikembangkan sedemikian rupa. ${ }^{18}$ Bahkan pada 1893 , terjadi

\footnotetext{
${ }^{14}$ Wawan Hernawan, Seabad, 55.

${ }^{15}$ Wawan Hernawan. Abdul Halim, 44.

${ }^{16}$ Jalaluddin, 372.

${ }^{17}$ Suwandi Wigena Prawira, "K.H. Abdul Halim dan Santi Asromo", Panji Masyarakat XVI, no. 177 (1975): 17-18.

${ }^{18}$ Menurut informasi Departemen Pendidikan dan Kebudayaan, ketika van Den Bosch menjadi Gubernur Jenderal (1829-1834) telah dirasakan bahwa tanpa bantuan penduduk bumiputera yang terdidik, baik untuk administrasi pemerintahan maupun pekerja bawahan, pembangunan ekonomi pemerintah Hindia Belanda tidak akan berhasil secara optimal. Untuk keperluan itu, setelah melalui prosedur yang bertele-tele, pada 1848 diterbitkan keputusan raja tertanggal 30 September 1848 No. 95 tentang pemberian wewenang kepada Gubernur Jenderal untuk menyediakan biaya $f 25.000$,- per-tahun bagi pendirian sekolahsekolah bumiputera di Jawa. Tujuan utamanya adalah untuk mendidik calon-calon pegawai negeri. Sebagai langkah awal, kemudian didirikan 20 sekolah negeri keresidenan. Selanjutnya,
} 
reorganisasi pendidikan dasar. ${ }^{19}$ Namun, seperti para orang tua lainnya dari kalangan masyarakat biasa, tampaknya ibu Abdul Halim segera mengubur niatnya untuk menyekolahkan para putranya ke sekolah Goubernement. Hal itu begitu disadarinya, karena yang diperbolehkan mengikuti pelajaran di sekolah-sekolah Gouvernement saat itu hanya anak-anak dari kalangan para tokoh dan orang-orang terhormat bumiputera saja. ${ }^{20}$ Karena itu, untuk mendapatkan pendidikan yang memadai, Abdul Halim dimasukkan ke pesantren. Alasan lainnya, kuat dugaan berkaitan dengan pendidikan agama yang telah ditanamkan Mutmainah kepada Abdul Halim dan para saudaranya sejak kecil. Dijumpai informasi, Abdul Halim sendiri, sejak usianya memasuki 10 tahun, karena dipandang sudah dapat membaca al-Qur'an, ia kemudian dimasukkan ke pesantren di Kampung Cideres, Dawuan. ${ }^{21}$ Ketika berada di pesantren Cideres, berkat pergaulannya ia mulai berlatih membaca dan menulis huruf latin serta bahasa Belanda kepada van Verhoeven. ${ }^{22}$

Pendidikan al-Qur'an di pesantren Kampung Cideres diselesaikan Abdul Halim dalam satu tahun. Berbekal kemampuan membaca al-Qur'an, membaca dan menulis huruf latin, serta dasardasar bahasa Belanda, di usianya memasuki

pada 1864 dikembangkan menjadi 186 buah. Lihat, Departemen Pendidikan dan Kebudayaan. Pendidikan di Indonesia dari Zaman ke Zaman (Jakarta: Dewan Penelitian dan Pengembangan Pendidikan dan Kebudayaan, 1979), 51.

${ }^{19}$ Pada 1893, untuk tingkatan Sekolah Dasar di kalangan Bumiputera dibagi menjadi dua kategori, yaitu: Pertama, Sekolah Dasar kelas satu, yaitu sekolah yang diperuntukkan bagi anak-anak dari kalangan pemuka, tokoh-tokoh terkemuka, dan orang-orang yang terhormat bumiputera. Kedua, Sekolah Dasar kelas dua adalah sekolah bagi anak-anak bumiputera kalangan bawah. Sumber ini menyebutkan, terdapat perbedaan pelaksanaan pembelajaran antara sekolah kelas satu dan kelas dua, yaitu: dari segi lama belajar, kurikulum, tenaga pengajar, dan uang sekolah. Hal-hal tersebut dimungkinkan menjadi pemicu keengganan para orang tua dari kalangan bawah untuk menyekolahkan anak-anak mereka ke sekolah Gouvernement. Ibid., 52.

${ }^{20}$ Ibid., 57.

${ }^{21}$ Wawan Hernawan, Abdul Halim, 44.

${ }^{22}$ Lihat, Th. Van den End, Sumber-sumber Zending tentang Sejarah Gereja di Jawa Barat 1858-1963. Seri Sumber-sumber Sejarah Gereja di Indonesia No. 3. Jakarta: BPK Gunung Mulia. Lihat pula, Jalaluddin, 373. sebelas tahun Abdul Halim mulai memperdalam ilmu agama Islam secara berkelanjutan dari pesantren ke pesantren. Mula-mula ia masuk ke pesantren Lontang Jaya, Panjalin, Leuwimunding. Melalui kyai Abdullah, ia belajar ilmu qira'at dan tajwid. ${ }^{23}$ Setelah dinyatakan lulus, ia pindah ke pesantren Bobos, Dukupuntang, Cirebon. Di pesantren ini, Abdul Halim menekuni Sastra Arab langsung kepada kyai Sudjak (K.H. Sudja'i). Setelah dipandang cukup menguasai, Abdul Halim melanjutkan pendidikan agamanya ke pesantren Ciwedus, Cilimus, Kuningan. Di Pesantren Ciwedus ia dibimbing oleh Kyai Sjaubari (Kyai Sobari). ${ }^{24}$ Setelah dinyatakan lulus, Abdul Halim pun melanjutkan pendidikan agamanya ke salah satu pesantren di Kedungwuni, Pekalongan, dan setelah itu kembali ke Ciwedus. ${ }^{25}$

Ketika usia Abdul Halim memasuki 21 tahun, yaitu awal 1908, ibunya (Siti Mutmainah) memanggil untuk segera pulang ke Jatiwangi. Setibanya di Jatiwangi, Siti Mutmainah sudah mempersiapkan calon istri untuknya, yaitu nyai Siti Murbiyah seorang gadis yang baru berusia 11 tahun. Siti Murbijah adalah putri bungsu K.H. Muhammad Ilyas, yang ketika itu menjabat sebagai Penghulu Landraad Kabupaten Majalengka. Dari silsilah keturunan, Abdul Halim dengan Siti Murbijah masih bersaudara dari pihak ibu. ${ }^{26}$

\footnotetext{
${ }^{23}$ Ibid., 374. Lihat, Wawan Hernawan, Seabad, 57.

${ }^{24}$ Lihat, Suwandi Wigena Prawira, "K.H. Abdul Halim", 17. Lihat pula, S. Wanta, KH Abdul Halim, 4.

${ }^{25}$ Wawan Hernawan. Teologi K.H. Abdul Halim Ikhtiar Melacak Akar-akar Pemikiran Teologi Organisasi Massa Islam Persatuan Ummat Islam (PUI) (Bandung: PW PUI Jawa Barat, 2007), 41. ${ }^{26}$ S. Wanta menyebutkan, Siti Mutmainah adalah putri dari K.H. Imam Safari, seorang ulama dan pendiri masjid Agung al-Imam Majalengka. Sementara nyai Siti Murbijah adalah anak dari Moechammad Iljas ibn Hasjim Basjari ibn Imam Safari. Dengan demikian, antara Abdul Halim dengan Siti Murbijah adalah antara paman dengan keponakan. Dari perkawinan itu, mereka dikarunia 7 orang putra dan putri, yaitu: 1) Moechammad Thoha, 2) Siti Fatimah, 3) Siti Mahrijah, 4) Abdul Aziez Halim, 5) Siti Halimah, 6) Abdul Karim, dan 7) Toto Taufik Halim. Lihat, S. Wanta, 4-5. Lihat pula, Sule, "Masjid Agung Al-Imam Usianya sudah 126 Tahun" dalam Sule/Sinarmedia.com; diakses pada 6 September 2015.
} 
Dengan demikian, terdapat dugaan, pernikahan mereka memiliki makna ganda, yaitu: selain menjalankan syari' at Islam, sekaligus pereratan tali keluarga. Model pernikahan demikian merupakan hal biasa dalam adat masyarakat pada waktu itu. ${ }^{27}$

Beberapa bulan setelah menikah, masih pada tahun yang sama (1908), Halim menunaikan ibadah haji. ${ }^{28}$ Suatu yang agak disesalkan, Halim tidak menjelaskan tentang perjalanannya, baik rute maupun tempat persinggahan dalam perjalanannya menuju ke Timur Tengah. Informasi yang diperoleh, di samping menunaikan ibadah haji, Halim bermaksud untuk melanjutkan pendidikan agamanya di sana. Hal itu terkait dengan pengakuan masyarakat bumiputera saat itu, bahwa seseorang baru dipandang matang dalam ilmu agama (Islam), apabila sudah naik haji. Kepercayaan masyarakatpun semakin kuat, apabila yang bersangkutan dapat melanjutkan studinya di sana. ${ }^{29}$

Mengenai tempat studi Halim selama di Timur Tengah, diduga kuat berada di pusat jaringan ulama Haramain. Terkait dengan hal itu, para penulis sebelumnya, misalnya Abu Sjahid Hidajat ${ }^{30}$ dan Jalaluddin, ${ }^{31}$ menyebut Abdul Halim belajar di Makkah. Masa studi Abdul Halim di Makkah bersamaan dengan masa studi K.H. Mas Mansoer (Muhammadiyah), K.H. Abdul Wachab Chasbullah (Nahdlatul Ulama), K.H. Ahmad Sanoesi (Al-Itthadijatoel Islamijjah), serta kawan-kawannya dari Sumatera. ${ }^{32}$ Dengan demikian, kuat dugaan

\footnotetext{
${ }^{27}$ Dalam tradisi masyarakat bihari (dahulu), perkawinan dengan saudara (dalam arti masih ada pertalian hubungan keluarga) sering dijadikan ajang untuk penyatuan keluarga yang sudah renggang dengan falsafah agar tidak terjadi pareumeun obor (kehilangan jejak silsilah keluarga) dan penyatuan harta yang sudah berserak. Lihat, Wawan Hernawan, Teologi, 41.

${ }^{28}$ Dari studi literer yang dilakukan peneliti dan dilanjutkan interview kepada beberapa informan yang dipandang mengetahui permasalahan, belum ditemukan informasi yang menyatakan Abdul Halim berangkat naik haji bersama istrinya pada tahun itu.

${ }^{29}$ Ibid., 42.

${ }^{30} \mathrm{Abu}$ Sjahid Hidajat, 19-20.

${ }^{31}$ Jalaluddin, 373.

${ }^{32}$ Selama studi di Makkah, Abdul Halim membaca dan
}

Abdul Halim belajar kepada para ulama yang menjadi guru kawan-kawan seangkatannya di atas. Di antara para guru di Haramain waktu itu adalah Syekh Ahmad Khatib Minangkabawi dan Syekh Ahmad Khayyat. ${ }^{33}$ Selain menjadi murid langsung Ahmad Khatib dan Ahmad Khayyat, Halim juga menyebut gurunya yang lain, yaitu Emir Sjakib Arslan dan Syekh Tanthawi Djawhari. ${ }^{34}$

Pada 1911, Abdul Halim dijemput keluarganya agar segera kembali ke tanah air. Menurut Wanta, ${ }^{35}$ para penjemput Abdul Halim adalah ibu mertuanya, Ny. Djamilah (Ny. Hj. Sjamsijah) dan kakak iparnya, H. Boerhanoel Asjikin. Dengan demikian, masa studi Abdul Halim di Timur Tengah hanya berlangsung kurang lebih tiga tahun. Sekembalinya ke tanah air, Halim tidak menggunakan lagi nama Mohammad Sjatari atau Otong Satori lagi, tetapi menggantinya dengan Abdul Halim. Nama itu tetap digunakannya hingga ia wafat di Balai Pamulangan Pondok Mufidat Santi Asromo Majalengka pada $1962 .{ }^{36}$

mendiskusikan sejumlah karya Jamaluddin al-Afghani dan Muhammad Abduh. Pada saat itu tema-tema tajdid (pembaharuan) yang dikemukakan al-Afghani dan Abduh menjadi pokok pembicaraan bersama para guru dan kawankawannya. Selain itu, Abdul Halim sangat terkesan dengan dua lembaga pendidikan yang ada di sana. Pertama, yang berada di Bab al-Salam (Makkah) dan kedua, lembaga pendidikan yang ada di Jeddah. Berbeda dengan lembaga pendidikan lainnya yang ia temukan selama di Makkah, keduanya telah menghapuskan sistem halaqah. Kedua model lembaga pendidikan itu kelak dijadikan model oleh Abdul Halim di Santi Asromo. Lihat, Deliar Noer, 80-81; Lihat pula, Wawan Hernawan, Seabad, 58.

${ }^{33}$ Karel A. Steenbrink, Beberapa Aspek tentang Islam di Indonesia Abad ke-19 (Jakarta: Bulan Bintang, 1984), 145-146. ${ }^{34}$ Sementara ini, peneliti belum berhasil mengidentifikasi lebih lanjut kedua ulama yang disebut terakhir, terutama bila ditelusuri dari sudut jaringan ulama Haramain pada abad ke-19. Informasi yang berhasil dihimpun, menyebutkan, Emir Syakib Arslan adalah salah seorang tokoh nasionalisme Arab. Sedangkan Syekh Tanthawi Djawhari seorang cendekiawan Mesir yang memotivasi kaum Muslim agar menguasai ilmu secara luas. Selain itu, diketahui, Syekh Tanthawi Djawhari adalah seorang ahli filsafat dan mufassir dengan corak tafsir bi al-ilm. Lihat, Lothrop Stoddard, Dunia Baru Islam, Terj. Dari bahasa Inggris oleh Panitia Penerbit (Jakarta: Panitia Penerbit), 320.

${ }^{35} \mathrm{~S}$. Wanta, 4.

${ }^{36}$ Lihat, S. Wanta, 5. Lihat pula, Wawan Hernawan, Abdul Halim and His, 50-51. 


\section{Ide Politik K.H. Abdul Halim}

Abdul Halim lahir dan tumbuh dalam situasi dan kondisi yang sangat tidak menguntungkan sebagai akibat dari kebijakan politik Pemerintah Hindia Belanda. Hal yang sama terus ia rasakan pada saat kepulangan dari masa studinya di Timur Tengah. Kondisi masyarakat bumiputera belum berubah, bahkan lebih memperihatinkan dari sebelumnya. Dijumpai informasi, segera setelah kepulangannya pada tahun 1911, ia mulai mempraktikan pengetahuan dan kemampuannya untuk membesut masyarakat bumiputera dari pola kehidupan fatalis dan statis, menjadi masyarakat yang berpengetahuan dan dinamis. Pada rentang 1911 sampai 1928, Abdul Halim telah mendirikan dan menjadi voorzitter masing-masing: Madjlisoel 'Ilmi (1911), Hajatoel Qoeloeb (1912), dan Persjarikatan Oelama (1916). ${ }^{37}$ Seiring dengan perkembangan Persjarikatan Oelama, Abdul Halim sebagai Voorzitter Hoofdbestuur (Ketua Pengurus Besar) menjalin kerjasama dengan Sarekat Islam (SI). Abdul Halim sendiri, menurut Noer, ${ }^{38}$ terlihat aktif dalam kegiatankegiatan Sarekat Islam pada 1918 atau mungkin sebelumnya. Aktivitas Abdul Halim di Sarekat Islam, masih tampak terlihat hingga 1933.

\section{Rukun Islam sebagai Landasan Berpikir}

Hingga di sini, meskipun Abdul Halim telah mempraktikkan seluruh semangatnya dalam perjuangan kaum Muslim dan bangsa Indonesia pada rentang 1911 hingga sebelum 1928, namun dokumen tertulis yang mencerminkan pemikiran politik yang ia kembangkan belum ditemukan. Dari heuristik yang peneliti lakukan, ia mulai mendokumentasikan pemikiran dan gerakan politik yang diamininya, diduga setelah diilhami oleh penerbitan majalah Al-Munir di Sumatera Barat. Pada 1928, ia mulai menerbitkan majalah bulanan Soeara Persjarikatan Oelama

\footnotetext{
${ }^{37}$ Lihat, S. Wanta, 11. Lihat pula Deliar Noer, 81. Bandingkan dengan Wawan Hernawan, Seabad, 68-69.

${ }^{38}$ Deliar Noer, 84
}

(Soeara P.O.). ${ }^{39}$ Selain itu, bersamaan dengan semakin terpolarisasinya kaum Muslim dalam berbagai pemahaman keagamaan, organisasi, dan kecenderungan politik, Abdul Halim juga menyusun Padoman Propaganda Persatoean Islam. ${ }^{40}$

Melalui Padoman Propaganda Persatoean Islam, Abdul Halim memulai basis pemikiran politiknya dengan menyatakan: "Roekoen Islam jang lima itoe mendjadi organisasi kekoeatan doenia Islam." " ${ }^{41}$ Bagi Abdul Halim, rukun Islam adalah fondasi politik dan kebangsaan bagi seluruh kaum Muslim. Ia menguraikan pointpoint rukun Islam sebagai berikut:42

“(1) Doea kalimat sjahadat maksoednja jaitoe boeat mengikat segenap manoesiajang beragama Islam kepada rohnja persaudaraan jang merika wadjib mengetahoeinja. Adapoen sekalian bangsa jang memegang kawat Islam (doea kalimat sjahadat) maka wadjiblah merika bertoendoek ta'loek di bawah perintah Allah dan membenarkan bahwa Kandjeng Nabi Moehamad s.a.w. mendjadi pesoeroehnja. (2) Maka mendiriken sembahjang itoe oentoek mendidik manoesia kepada doea djalan: satoe oeroesan filosoof (acherat) dan kedoeanja dalam praktijknja sembahjang mendjadi organisatie Politiek dan mengandoeng democratie, karena dengan mengerdjakan sembahjang hilanglah deradjat tinggi dan rendah, kaja dan miskin, mendjadi pimpinannja salah satoe Imam jang terpilih dari salah satoenja dari pada merika jang bersembahjang tadi. (3) Poeasa jaitoe mendjadi didikan kepada manoesia

\footnotetext{
${ }^{39}$ Majalah bulanan Soeara Persjarikatan Oelama (Soeara P.O.), diterbitkan bagi masyarakat luas yang bukan kalangan internal organisasi Persjarikatan Oelama, akan tetapi ummat Islam pada umumnya. Soeara P.O., diterbitkan untuk pertama kalinya pada 1928 dan terbit secara periodik selama lima tahun sampai edisi Desember 1932 dengan sejumlah 60 nomor penerbitan. Para penulis Soeara P.O. terdiri dari anggota Persjarikatan Oelama dan simpatisan yang merefleksikan pandangannya sehaluan dengan Persjarikatan Oelama. Materi utama yang disajikan dalam Soeara P.O. meliputi: akidah, ibadah, akhlak seorang Muslim, al-Qur'an, al-Hadis, termasuk peran agama dalam gerakan nasional dan masalah-masalah internasional. Lihat, Wawan Hernawan, Seabad, 73.

${ }^{40}$ Ibid., 88.

${ }^{41}$ Abdulchalim, Padoman Propaganda Persatoean Islam (Madjalengka: Hoofdbestuur Persjarikatan Oelama. KITLV, 1928), 2.

${ }^{42}$ Ibid., 2-4.
} 
dengan bersama-sama lapar, sehingga merasa pajahnja menahan lapar itoe, mendjadi timboel perasaan belas kasihan dari pada merika, djika melihat orangorang miskin dan melarat soeda tentoe tida membiarkannja. Dan laen dari itoe mendjadi politiek djoega bagi segenap kaoem Moeslimin, wadjib bekerdja bersama-sama di dalam kesoesahan dan kesenangan goena mengerdjakan perintah Allah. (4) Membri zakat, jaitoe organisatie jang penting bagi socialisme dalam Islam, bahwa orang-orang jang miskin dengan orang-or ang jang kaja berkenalan rapattjinta mentjinta di antara merika, jang mana dengan lantaran pembrian zakat tadi mendjadi persaoedaraan rapat di antara orang-orang jang kaja dan miskin. Lain dari pada itoe ada djoega sebagai kelebihannja dari itoe, dimasoekan kedalam baitoelmal tersedia oentoek keperloean oemoem. (5)Adapoen hadji ja'ni diwadjibkan bagi tiap-tiap orang Islam jang berkewasa mengoendjoengi Mekkah, dan Mekkah ini mendjadi "Daaroennadwah" (tempat membitjarakan roepa-roepa keperloean jang mengenai badan Islam) baik oeroesan penghidoepan dan kemadjoean, maoepoen oeroesan Ibadat (ethies)'”.

Melanjutkan pemikiran politiknya, masih dalam Padoman Propaganda Persatoean Islam, Abdul Halim mengemukakan kegelisahannya dengan mengulas Sababnja Rendahnja Kaom Moeslimin pada Déwasa Ini, sebagai berikut:43

"Kaom Islam didalam doenia pada masa ini sebagian jang terbesar ta'dapat dimoengkiri lagi, adalah dalam hal kelembékan dan perhinaan jang amat berlawanan dengan jang semestinya mengingat riwajat tarich Islam jang begitoe moelia, dan djandjidjandji kepada kaoem Islam begitoe njata, terkandoeng dalam Qoer'an jang soetji. Akan tetapi boektinja dalam masa ini bangsabangsa jang tergolong didalam kaom Islam itoe, ketjoeali satoe doea dalam Politiek, mendjadi perhambaän, sedang satoe doea bangsa jang bebas dari perhambaän itoe, ta' dapat daja-oepaja jang tjoekoep akan melepaskan sesama kaom Islam, dalam bangsabangsa laen itoe dari perhambaännja dalam

${ }^{43}$ Ibid., 4-5. kemadjoean pengetahoean, mendjadi menoeroet dalam kalangan perniagaan dan peroesahaan, mendjadi pengambil oepah, atau seolaholah kolah aer tempat orang laen mengambil keperloeannja.... Adapoen sebab-sebabnja itoe, laen tida karena kita kaom Islam menoenai atas djangdji kepada Toehan jang telah terseboet dalam Qoer'an, dan djoega haroes diakoei sesoenggoehnja kekurangan bagi kita kaom Moeslimin tentang doea perkara: Satoe ilmoe dan kedoeanja persatoean. Maka wadjib bagi tiap-tiap kaom Moeslimin menghabiskan perbantahan diantara merika jang timboel dari perselisihan dan mengatoer ilmoe (pengetahoean kita Islam)".

Masih dalam Padoman Propaganda Persatoean Islam, Abdul Halim melanjutkan pemikiran politiknya yang diduga ditujukan kepada para penentangnya, sebagai berikut:

“... Tegasnja selamanja kaom Moeslimin masih soeka mementingkan keperloeannja sendiri sahadja dan tida memperdoelikan kemaslahatan oemoem, nistjajalah bangsa Islam kita soesah akan berdiri tegak. Karena bagai saja peonja pendapatan menoeroet kitab-kitab Islam, barang siapa jang memikirkan keperloean oemoem, nistjaja dirinja sendiri termasoek, sebaliknja kalau orang itoe memikir hanja keperloean sendiri, soedah tentoe lainnja itoe tidak termasoek". ${ }^{44}$

\section{Selain menulis Padoman Propaganda} Persatoean Islam, Abdul Halim juga menulis Padoman Persjarikatan Oelama pada 1932. Dalam buku kedua ia menggambarkan situasi dan kondisi masyarakat bumiputera, sebagai berikut: 45 "Berhoeboeng dengan keadaan hidoep manoesia dalam doenia pada masa sekarang ini ada didalam kekoesoetan tiap-tiap hari semangkin tambah kekaloetannja didalam pergaoelan hidoep manoesia si koeat menindas si lemah, si kaja mengisap si miskin, si pandai memoetar si bodo dan jang berkoeasa mempergoenakan kekoesaannja dan kelebihannja hanja boeat memenoehi nafsoe dan kemenangannja diri sendiri sahadja. Maka doenia sudah mendjadi

\footnotetext{
${ }^{44}$ Ibid., 11. Lihat pula, Wawan Hernawan. Seabad, 89.

${ }^{45}$ Abdulchalim, Padoman Persjarikatan Oelama (Madjalengka: Hoofdbestuur Persjarikatan Oelama. KITLV, 1932), 6.
} 
soenji dari pada sifat tolong menolong tjinta mentjinta, dan didalam pergaoelan hidoep tida mempoenjai perasaan saling menanggoeng (verantwoordelijk heidsgevoel)".

Berdasarkan situasi dan kondisi tersebut, lanjut Abdul Halim, ${ }^{46}$ Persjarikatan Oelama berhajat: pertama, memadjoekan dan menggembirakan pengadjaran Islam. Kedua, memadjoekan dan menggembirakan hidoep dan kehidoepan setjara Islam. Namun demikian, Abdul Halim berpesan:47 "hidoeplah Persjarikatan Oelama djangan kamoe mentjari hidoep didalamnja, agar soepaja tida mati!! Moeliakanlah P.O. djangan kamoe mentjari ketinggian dirimoe didalamnja soepaja P.O. tida terhina". ${ }^{48}$ Persjarikatan Oelama, demikian Abdul Halim, "haroes memadjoekan kaperloean harta bendanja lid-lid teroetama hartanja oelama-oelama igama Islam, haroes memelihara tali pertjintaannja di antara lid-lidnja dan membangoenkan hati marika itoe akan soeka tolong menolong satoe sama laen". ${ }^{49}$

\section{Konsep Al-Salam}

Pemikiran politik dari Abdul Halim selanjutnya tercermin pada konsep al-Salam. Konsep politik al-Salam dimulai dari pemikiran Abdul Halim tentang upaya untuk membina keselamatan hidup di dunia agar kelak dapat diperoleh kesejahteraan hidup di akhirat. Upaya tersebut berupa perbuatan yang harus dilakukan pada aspek-aspek tertentu dalam kehidupan manusia guna menyelaraskannya dengan tuntunan agama. ${ }^{50}$ Bagi Abdul Halim, agama (Islam) berisi tentang konsep-konsep (ajaran) yang bertujuan memberikan bimbingan kepada umat manusia agar mereka dapat hidup selamat di dunia sekaligus memperoleh kesejahteraan kehidupan di akhirat. ${ }^{51}$ Ia menyatakan demikian, karena

\footnotetext{
${ }^{46}$ Ibid., 7.

${ }^{47}$ Ibid., 13.

${ }^{48}$ Ibid.

${ }^{49}$ Ibid., 20.

${ }^{50}$ Jalaluddin, 100-101.

${ }^{51}$ Ibid., 101.
}

menurutnya kesejahteraan hidup seseorang di akhirat erat hubungannya dengan keselamatan seseorang selama hidup di dunia. ${ }^{52}$ Untuk itu bagi Abdul Halim, sarana untuk memperoleh kehidupan yang sejahtera di akhirat, terlebih dahulu seseorang harus hidup dengan selamat di dunia. Hidup selamat dimaksud adalah hidup yang sesuai dengan konsep-konsep (ajaran) agama. ${ }^{53}$ Untuk itu, demikian Abdul Halim, antara kedua kehidupan tersebut (dunia dan akhirat) terdapat hubungan timbal-balik satu sama lain. ${ }^{54}$

\section{Konsep Ishlah al-Samaniyah}

Lebih lanjut, bagi Abdul Halim, al-Salam baru akan diperoleh setelah seseorang melakukan upaya Ishlah (perbaikan). Ishlah (perbaikan) yang dimaksud ialah setiap individu, kelompok, masyarakat, bahkan bangsa harus melakukan Ishlah (perbaikan). Perbaikan itu meliputi: tata keyakinan, tata peribadatan, tata keluarga, tata adat, tata ekonomi, tata sosial, dan tata ummat. Ishlah (perbaikan) itulah yang kemudian dikenal dengan sebutan delapan macam perbaikan hidup (al-ishlah al-samaniyyah), meliputi: 1) al-ishlah al-'aqidah (perbaikan akidah); 2) al-ishlah al-'ibadah (perbaikan ibadah); 3) al-ishlah al'ailah (perbaikan keluarga); 4) al-ishlah al-'adah (perbaikan adat-istiadat); 5) al-ishlah al-tarbiyah (perbaikan pendidikan); 6) al-ishlah al- 'iqtishad (perbaikan ekonomi); 7) al-ishlah al-ijtima' (perbaikan sosial); dan 8) al-ishlah al-ummah (perbaikan ummat). ${ }^{55}$

Kelanjutan dari konsep al-salam dan al-ishlah (perbaikan), yang paling mendesak saat itu adalah al-ishlah al-tarbiyah (perbaikan pendidikan). Pemikiran politik pendidikan diduga merupakan gagasan Abdul Halim dari perlunya suatu upaya serius guna perbaikan pendidikan kaum Muslim. Semula upaya perbaikan pendidikan yang

\footnotetext{
${ }^{52}$ Ibid.

${ }^{53}$ Abdul Halim, Risalah Penoendjoek Bagi Sekalian Manoesia (Tasikmalaja: Galunggung Drukerij, 1938), 1-2.

${ }^{54}$ Jalaluddin, 101.

${ }^{55}$ Lihat, Moh. Akim. Kiai H. Abdul Halim Penggerak PUI (Majalengka: Yayasan K.H. Abdul Halim), 49-62.
} 
dilakukan Abdul Halim terbatas pada kegiatan penyelenggaraan madrasah dan sekolah agama di lingkungan Persjarikatan Oelama. ${ }^{56}$ Namun dalam perkembangannya, karena dirasa olehnya tidak cocok lagi dengan kebutuhan stakeholders (masyarakat), ia kemudian memilih tempat pendidikan di sebuah lokasi yang jauh dari kebisingan kota. Hal itu sebagaimana dipahami dari pernyataan Abdul Halim, ${ }^{57}$ sebagai berikut:

"... mengadakan sebuah tempat pendidikan dan pengajaran yang jauh dari tempat yang ramai, agar kelak kemudian hari anak-anak sesudahnya dewasa dapat mengerti tujuan hidupnya dan bekerja dengan tenaganya sendiri dengan ikhlas dan ridha".

Tempat yang jauh dari tempat yang ramai, menurut Abdul Halim merupakan tempat ideal guna mewujudkan cita-citanya. Ia menyatakan:

“... di tempat-tempat yang ramai yang kebanyakan tidak menurut aturan-aturan syar' $i$, sangat susahlah bagi kita menanam pendidikan yang menurut tuntunan Illahi, sebab banyak godaan-godaannya, maka terpaksalah kita musti mengasingkan tempat pendidikan itu ke tempat yang sepi dari kekotoran dan godaan, agar supaya pendidikan itu bisa hidup subur serta kuat di ahti anakanak kita". ${ }^{58}$

Dari pernyataan Abdul Halim tersebut dapat dipahami, bahwa sedikitnya terdapat dua masalah krusial dalam pendidikan ketika itu. Pertama, tempat (lingkungan) pendidikan yang berada di pusat-pusat kota sudah kurang sesuai dengan tujuan pendidikan itu sendiri, terutama dalam pembentukan moral anak didik. Kedua, dari sisi tujuan pendidikan, sudah tidak sejalan dengan kebutuhan stakeholders (masyarakat). Menurut Abdul Halim, model pendidikan yang dibutuhkan masyarakat ketika itu adalah membentuk anak didik agar kelak setelah selesai mengenyam pendidikan, ia memiliki akhlak mulia, berilmu,

${ }^{56}$ Ibid., 17. Lihat pula, Karl A. Steenbrink, 73.

${ }^{57}$ Abdul Halim, "Jalan Sempurna ke Arah Kebahagiaan Dunia Akhirat", Catatan Harian/Manuskrip. (T.tp.: Tp., T.th.), 1.

${ }^{58}$ Deliar Noer, 83. dan terampil. ${ }^{59}$ Untuk itu, ia memilih lokasi pendidikan barunya di sebuah perbukitan di daerah Pasir Ayu, Majalengka. Menurutnya, lokasi itu sangat cocok untuk pembentukan akhlak seperti yang dilakukan Rasulullah Saw., di gua Hira, Jabal Nur, Makkah. ${ }^{60}$ Aspek lain yang menjadi perhatian Abdul Halim adalah adatistiadat yang berkembang di masyarakat sekitar lokasi pendidikan barunya. Menurutnya, adatistiadat yang berkembang di masyarakat selama tidak bertentangan dengan ajaran-ajaran Islam yang prinsip harus dipelihara dan dipertahankan. ${ }^{61}$

\section{Konsep Santi Asromo}

Pemikiran politik pendidikan Abdul Halim selanjutnya adalah lingkungan pendidikan harus sesuai dengan usaha masyarakat, terutama guna peningkatan pendapatan masyarakat setempat. Dengan demikian, sebuah tempat pendidikan yang menjadi pemikiran Abdul Halim, kuat dugaan merupakan perpaduan antara nilai-nilai agama, adat, dan kegiatan-kegiatan praktis yang dapat meningkatkan nilai ekonomi bagi masyarakat lingkungan lembaga pendidikan itu berdiri. Karena itu, Abdul Halim kemudian merumuskan sistem pendidikan pesantren yang dalam kurikulumnya dimasukkan sejumlah mata pelajaran keterampilan. Ia menamakan lembaga pendidikan barunya "Santi Asromo", 62

\footnotetext{
${ }^{59}$ Jalaluddin, 137.

${ }^{60}$ Ibid., 138

${ }^{61} \mathrm{Ibid}$.

${ }^{62}$ Santi Asromo adalah lembaga pendidikan yang didirikan Halim pada 1932 di Pasir Ayu Maja, Majalengka. Berdasarkan pengumuman yang disampaikan Hoofdbestuur Persjarikatan Oelama Madjelis Pergoeroean, berbeda dengan madrasahmadrasah P.O. lainnya, ciri penting Santi Asromo adalah: Pertama, sistim yang digunakan adalah pondok pesantren, yaitu selain pelajaran agama dan pengetahuan umum seperti Sejarah Dunia dan Bahasa Belanda, diajarkan pula praktik bercocok tanam, tukang kayu (meubeler), kerajinan tangan, dan lainlain yang dimaksudkan untuk memenuhi pendidikan aqliyah (intellect), pendidikan ruhaniyah (geestelijk), dan pendidikan amaliyah (praktijk). Kedua, tujuan yang ingin dicapai adalah kelak peserta didik dapat mencari rizki yang halal dan tidak membutuhkan pertolongan orang luar, bahkan berangsur-angsur dapat berusaha self help (memenuhi kebutuhan sendiri) dan auto activiteit (percaya pada diri sendiri), menjadi santri lucu bukan menjadi santri kaku. Ketiga, wajib tinggal di asrama (pondok) selama 5 atau 10 tahun dengan membawa bekal beras 50 kati
} 
yaitu sebuah lembaga pendidikan terpadu, meliputi: pendidikan agama, bengkel kerja, dan masyarakat. Dalam hubungan fungsinya tersebut, kemudian diberi nama Balai Pamulangan Pondok Mufidat Santi Asromo. ${ }^{63}$

Masih kelanjutan dari pemikiran al-salam dan al-ishlah yang berujung dengan perlunya didirikan Santi Asromo, Abdul Halim masih merasa khawatir dengan para lulusan sekolah waktu itu, baik tamatan lembaga pendidikan Gouvernements (pemerintah) maupun tamatan lembaga pendidikan Islam. Menurutnya, para lulusan kedua lembaga itu seperti kurang fungsional. Keduanya masih memiliki banyak kelemahan. Para tamatan pendidikan gouvernements (pemerintah) hidupnya sangat bergantung kepada lowongan kerja pada instansi pemerintah. Dalam keseharian, mereka cenderung menganggap diri sebagai golongan terpelajar yang sangat layak untuk mendapat pekerjaan di instansi pemerintah. Kebanyakan dari mereka juga merasa enggan untuk bekerja pada sektor-sektor lainnya. ${ }^{64}$ Sebaliknya, para tamatan madrasah dan pesantren lebih parah lagi. Mereka banyak yang menjadi penganggur, karena lapangan pekerjaan di almamaternya hanya terbatas pada bidang pendidikan yang tidak mungkin menampung semua lulusannya. Lebih dari itu, setelah mereka pulang ke kampung halamannya masing-masing

dan uang $f 0,60$ (enam puluh sen) yang disetor kepada pengurus setiap bulan (sebagai ganti SPP), dan peserta didik harus membawa alat pelajaran sendiri. Santi Asromo menerapkan sistem pendidikan yang berbeda dibanding sistem pendidikan madrasah, sekolah, dan pesantren yang ada pada waktu itu. Santi Asromo terletak di Desa Pasir Ayu, Kecamatan Sukahaji, Kabupaten Majalengka dengan luas area \pm 15 Ha., menempati daerah di kaki bukit Pasir Batang, yang jauhnya $\pm 17 \mathrm{Km}$ ke arah Timur Laut Kota Majalengka. Meskipun secara geografis letaknya cukup jauh dari ibu kota kabupaten, namun tidak berarti menempati lokasi yang terpencil. Santi Asromo dikelilingi oleh tujuh buah desa, yaitu: 1) Pagaraji, 2) Cicalung, 3) Ciomas, 4) Padahanten, 5) Belisuk, 6) Sindang, dan 7) Garawastu. Lihat, Akim, 31; Lihat pula, Jalaluddin,147-148; Bandingkan dengan S. Wanta, 18-19.

${ }^{63}$ Dartum Sukarsa, Potret K.H. Abdul Halim dalam Eksistensi Nasionalisme dan Perbaikan Umat (1887-1962) (Bandung: Sarana Panca Karya Nusa, 2007), 103.

${ }^{64}$ Djunaidi M. Mansur, "Penjelasan Maksud dan Tujuan Pendidikan PUI", Diktat (Majalengka: Tp., 1969), 3. tidak mampu menciptakan lapangan kerja, karena tidak dibekali skill (keterampilan). Setelah pulang, mereka lebih banyak menjadi petani dan bahkan buruh tani. ${ }^{65}$

Abdul Halim berkesimpulan, paling tidak terdapat tiga faktor penting yang dapat mendorong usaha manusia untuk meningkatkan perikehidupannya di dunia. Pertama, pertanian; kedua, pertukangan, dan ketiga, perdagangan. ${ }^{66}$ Untuk mencapai hal-hal tersebut, Abdul Halim menyatakan, bahwa pendidikan Islam semestinya dapat menjamin kesejahteraan hidup kaum Muslim, bukan membiarkan mereka dalam kebodohan dan kemiskinan. ${ }^{67}$ Pendidikan Islam bukan hanya difungsikan untuk pemenuhan kehidupan ukhrawi, tetapi justru menyeru setiap kaum Muslim untuk tidak melupakan kehidupan mereka selama di dunia. Untuk itu, tujuan pendidikan kaum Muslim harus diubah. Menurut Abdul Halim, tujuan pendidikan harus diarahkan pada usaha mendidik anak-anak agar kelak mereka dapat hidup mandiri di masyarakat. Melalui pendidikan, diharapkan para tamatan sesuai dengan jenjangnya mampu mencari rizki yang halal dan memberikan bantuan kepada orang lain yang membutuhkan. ${ }^{68}$

\section{Konsep Santi Lucu}

Sistem pendidikan yang diinginkan Abdul Halim adalah sistem pendidikan yang mampu membentuk kepribadian anak didik dan memberi kesempatan kepada mereka untuk meraih suatu jabatan berbasis skill (keterampilan) yang terlatih. ${ }^{69}$ Untuk itu, tujuan akhir (goal) dari pendidikan di Santi Asromo adalah menjadi "Santi Lucu", yaitu seorang santri yang memiliki skill (keterampilan), ilmu pengetahuan, dapat

\footnotetext{
${ }^{65}$ Abdul Halim, Jalan Sempurna, 1; Lihat, Djunaidi M. Mansur, 3. ${ }^{66}$ Halim, Abdul, "Santi Asromo", dalam Brosur Santi Asromo (Majalengka: Santi Asromo, t.th.), 1.

${ }^{67}$ Abdul Halim (ed.). Ketetapan Pengajaran di Sekolah Ibtidaiyyat Persjarikatan Oelama (Majalengka: Sederhana, 1934), 6-7.

${ }^{68}$ Abdul Halim, "Kaum Muslimin Harus Insaf!" dalam $A s-$ Sjoero, Majalah VI, no. 5 (1935): 168.

${ }^{69}$ Karl A. Steenbrink, 75.
} 
bekerja dalam berbagai lapangan kehidupan secara mandiri, serta mampu membantu orang lain yang memerlukan. Kuat dugaan, karena waktu itu bidang pertanian menjadi elan vital di tanah air, secara tegas Halim menyatakan, "santi lucu" adalah santri yang terampil memegang pena dan cangkul. ${ }^{70}$

\section{Konsep Intisab}

Pemikiran penting lainnya dari Abdul Halim dalam terma politik adalah konsep Intisab. Pemikiran ini lahir sebagai doktrin tandingan yang ditujukan kepada pemerintah Pendudukan Jepang seiring munculnya ajaran yang dipaksakan kepada kaum Muslim untuk melakukan seikerai ${ }^{71}$ (menghormat Kaisar Tenno Heika dengan menundukkan badan ke arah Tokyo). ${ }^{72}$ Untuk kepentingan itu, Abdul Halim dan sejumlah unsur pimpinan Persjarikatan Oelama (P.O.) berkumpul di Sekretariat PB P.O. di Majalengka. Mereka adalah: Djunaidi Mansur, Abdoel Wahab, Bunyamin Ma'ruf, Ahmad Nawawi, dan Abdullah Yasin Basyuni. Rujukan yang digunakan Abdul Halim dan para pimpinan P.O. dalam merumuskan intisab, selain bersumber kepada al-Qur'an juga dirujuk kitab al-Washiyah al-Dzahabiyah ${ }^{73}$ karya Syekh Mahmud Abu al-Faidl al-Manufi. ${ }^{74}$ Karena itu, gagasan Intisab bertolak dari aqidah Islamiyah, sebab pada awalnya diperuntukkan

\footnotetext{
${ }^{70}$ Jalaluddin, 146.

${ }^{71}$ Dalam ajaran Shintoisme diyakini, bahwa Kaisar Jepang Tenno Heika adalah keturunan Dewa Matahari (Amaterazu Omikami). Amaterazu Omikami diyakini sebagai tuhan yang mahakuasa, pemilik semesta alam yang telah mengkaruniai kehidupan bagi ras Yamato. Lihat, Wawan Hernawan, Seabad, 238-240.

${ }^{72}$ Ibid., 240.

${ }^{73}$ Menurut penuturan Abdullah Yasin Basyuni kepada Djuwaeni dalam wawancara pada 21 Januari 1990, Abdul Halim menciptakan intisab bersumber dari al-Qur'an, al-Hadits dan beberapa kitab, di antaranya: al-Washiyah al-Dzahabiyah, Muhammad Matsalu al-A'la dan Perikehidupan Muhammad Saw. Lihat, Ahmad Djuwaeni, "Arti dan Makna Intisab", Makalah (Jakarta: PB PUI, t.th.), 3.

${ }^{74}$ Syekh Mahmud Abu al-Faidl al-Manufi adalah salah seorang ulama Mesir dan $d a ' i$ generasi pertama setelah era al-Afghani dan Abduh. Al-Manufi dikenal sebagai pelanjut tariqat Syadziliyah, yaitu kelompok tarekat yang aktif dalam bidang diniyah (keagamaan), shufiyah (ahli tasawuf), ilmiah, dan falsafah. Lihat, Ibid. Lihat pula, Wawan Hernawan, Seabad, 240.
}

sebagai syarat bagi orang yang akan masuk ke dalam tarekat tersebut. Abdul Halim sendiri terinspirasi oleh al-Manufi, sebab bagi Abdul Halim akidah dapat memelihara manusia dari kekafiran, kemunafikan, dan kemusyrikan. ${ }^{75}$ Teks intisab yang dirumuskan Abdul Halim dan para pimpinan P.O. secara keseluruhan menurut S. Wanta, sebagai berikut: ${ }^{76}$

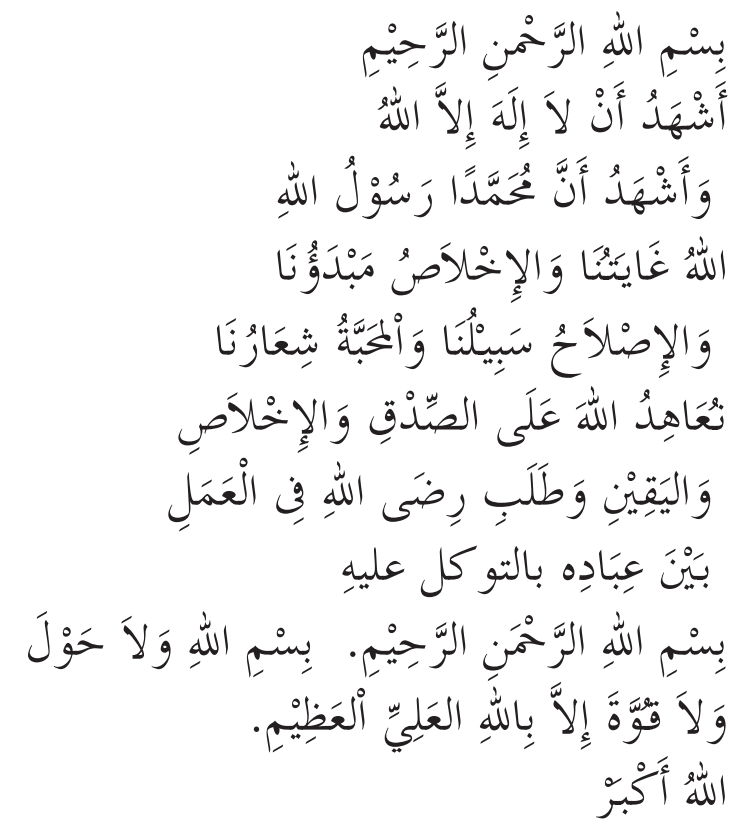

\section{Gerakan Politik K.H. Abdul Halim}

\section{Masa Pemerintahan Hindia Belanda}

Beberapa saat setelah kembalinya Abdul Halim dari masa studinya di Timur Tengah, masih pada 1911 ia segera mendirikan sebuah lembaga pendidikan yang dinamainya, Madjlisoel 'Ilmi. Untuk pertama kalinya lembaga ini menempati langgar berukuran tidak lebih $8 \mathrm{M}^{2}$ dan bertiang bambu. Para murid Madjlisoel 'Ilmi sejumlah tujuh orang, masing-masing: Sjafari, Abdoelfatah, Adnan, Ahmad Sjoto, Oemar Djahoeri, Djamaloeddin Kosim, dan Zoehri. ${ }^{77}$

\footnotetext{
${ }^{75}$ Ahmad Djuwaeni, "Pengetahuan Mahasiswa terhadap Intisab dalam Hubungannya dengan Kesadaran Berorganisasi di Lingkungan Perguruan Tinggi PUI Suatu Kajian Empiris" (Tesis S yang tidak dipublikasikan, IAIN Syarif Hidayatullah, 1990), 63. ${ }^{76}$ S. Wanta, Intisab PUI Lahir Penjelasan dan Penerangannya (Majalengka: PB PUI Majelis Penyiaran Penerangan dan Dakwah, 1987), 8.

${ }^{77}$ Abdulchalim, Padoman Persjarikatan, 4.
} 
Pada 1912, Abdul Halim mengganti nama Madjlisoel 'Ilmi dengan Hajatoel Qoeloeb. Fokus gerakannya mulai diperluas tidak hanya pada bidang pendidikan, tetapi mulai memerhatikan masalah ekonomi kaum bumiputera. ${ }^{78}$ Gerakan Hajatoel Qoeloeb, sekalipun dapat dimasukkan ke dalam pemahaman tradisionalis dalam fiqhnya, namun mereka tidak mempersoalkan furu' (cabang) dalam pemahaman keagamaan. Bagi mereka, hal-hal furu'iyah diserahkan kepada pilihan masing-masing individu. Terdapat informasi, meskipun sudah berjalan kurang lebih dua tahun, lembaga pendidikan Hajatoel Qoeloeb belum menggunakan nama resmi sampai datang kunjungan Sayid Hasyim al- 'Ashimi dari Jakarta pada 1914. Waktu itu Sayid Hasyim memberi nama Madrosatut Tholibin li Faroididdin. ${ }^{79}$ Meskipun demikian, usia Hajatoel Qoeloeb tidak lama. Hal itu sebagai akibat dari sering terjadinya perang mulut dan bahkan perkelahian fisik antara anggotanya dengan para pedagang China. Akibatnya, pada 1915 seluruh aktivitas Hajatoel Qoeloeb termasuk Madrosatut Tholibin li Faroididdin secara resmi dinyatakan dilarang. ${ }^{80}$

Didasari oleh rasa khawatir terhadap keadaan pendidikan masyarakat bumiputera (Islam) di daerahnya, pada Rabu 16 Mei 1916 sejumlah tokoh Majalengka yang terdiri atas guru, agamawan, dan perwakilan masyarakat mengadakan pertemuan di Kantoor Priesterraad (Kantor Penghulu) Kabupaten Majalengka. Mereka adalah: K.H. Iljas, M. Setjasentana, Habib Abdoellah Al-Djufri, M.H. Zoebedi, Hidajat, Sastrakoesoema, Atjung Sahlan, dan Abdul Halim. ${ }^{81}$ Dalam pertemuan itu dihasilkan dua buah kesepakatan, yaitu: pertama, mendirikan perhimpunan Persjarikatan Oelama (P.O.). Kedua, tugas utama perhimpunan P.O. adalah mendirikan madrasah yang kemudian

\footnotetext{
${ }^{78}$ A. Darun Setiady (ed.), Revitalisasi Peran PUI dalam Pemberdayaan Ummat (Bandung: PW PUI Jawa Barat, 2006), 252. ${ }^{79} \mathrm{~S}$. Wanta, Intisab, 11. Lihat pula, Wawan Hernawan, Seabad, 68. ${ }^{80}$ Deliar Noer, 81.

${ }^{81}$ Abdulchalim. Padoman Persjarikatan, 4. Lihat pula Wawan Hernawan, Abdul Halim and His, 45.
}

diberi nama Djam 'ijjat I'anat al-Muta'allimin..$^{82}$ Dalam tempo singkat, madrasah Djam'ijjat I'anat al-Muta'allimin terkenal sebagai satusatunya pusat pendidikan Islam modern di Majalengka. Ciri penting dari madrasah ini adalah diterapkannya sistem klasikal (kelas) dengan lama pendidikan lima tahun. ${ }^{83}$

Perkembangan yang cepat pada madrasah Djam 'ijjat I'anat al-Muta'allimin sebenarnya sudah dirasakan sejak pertengahan 1918. Hal itu segera berimbas pada kurang tersedianya guru. Dalam keadaan "darurat guru”, pada 1919 Abdul Halim sebagai voorzitter Hoofdbestuur P.O. memberikan kepercayaan kepada M. Setjasentana untuk menyusun leerplan (kurikulum) sekolah setingkat Kweek School (pendidikan guru). Pendirian Kweek School tidak lepas dari dukungan mertua Abdul Halim, yaitu K.H. Iljas dibantu Imam Hasan Basjari, dan Abdoel Ghani. ${ }^{59}$ Sekolah itu kemudian diberi nama Kweek School Moe'alimien. Untuk sementara, Kweek School Moe'allimien P.O. ${ }^{60}$ menempati rumah milik Soedjarwo. ${ }^{61}$ Mulai 1921, Kweek School Moe'allimien P.O. memiliki gedung sendiri di atas tanah milik Abdoelghani, Penningmeester (Bendahara) Hoofdbestuur P.O. ${ }^{84}$

Pada perkembangannya, ketika dilaksanakan konferensi Pendidikan P.O. pada 19-20 November 1932 di Majalengka, nama Kweek School Moe'allimien P.O. diubah menjadi Madrasah Daaroel Oeloem. Sedangkan untuk menampung para siswa putri, kemudian didirikan Kweek School Fathimiyah. Nama tersebut diambil dari nama organ wanita P.O., yaitu Fathimiyah. Madrasah Daaroel Oeloem Putra dan Fathimiyah putri berkembang cukup pesat. Para pelajar dari berbagai daerah terus berdatangan. Selain berasal dari daerah pelosok Jawa Barat, di antara mereka ada yang berasal dari Lampung, Jakarta, Pare,

\footnotetext{
${ }^{82}$ Abdulchalim. Padoman Persjarikatan, 5. Lihat pula, Wawan Hernawan, Seabad, 69.

${ }^{83}$ Ibid.

${ }^{84}$ Ibid., 71.
} 
Kediri, Banyumas, Kudus, Semarang, dan Tegal. ${ }^{85}$

Sejak berdiri pada 16 Mei 1916, Persjarikatan Oelama sebagai sebuah organisasi pergerakan telah melaksanakan kongres secara periodik. Menurut catatan resmi P.B.P.O., hingga April 1938, organisasi pergerakan ini telah melaksanakan kongres ke-15. ${ }^{86}$ E. Gobee, seorang adviseur voor inlandsche zaken dalam laporannya kepada tuan G.G. tentang pelaksanaan Kongres Persjarikatan Oelama IX pada 1931, menyebutkan, "Persjarikatan Oelama adalah organisasi yang berasaskan politik-agama. Gerakannya mirip dengan Partai Sarekat Islam Indonesia (PSII), namun jauh lebih moderat. Mereka aktif dalam bidang pendidikan, dakwah (Islam), dan penguatan ekonomi bumiputera. ${ }^{87}$ Selain pada Kongres IX (1931), kongres P.O. yang mendapat perhatian pemerintah Hindia Belanda adalah Kongres XIII di Indramayu. Lagi-lagi, E. Gobee dalam laporannya tertanggal 23 September 1935 kepada tuan G.G., menyebutkan, bahwa kongres ke-13 Persjarikatan Oelama merupakan pertemuan tahunan yang dihadiri oleh 38 cabang dan 50 perwakilan sekolah Persjarikatan Oelama. ${ }^{88}$

Menyadari perkembangan yang luar biasa pada organisasi pergerakan Persjarikatan Oelama, mulai 1936, Abdul Halim dan Kelan (Ketua dan Sekretaris Hoofdbestuur) P.O., kembali mengajukan perubahan badan hukum. Dalam ajuan perubahannya, Persjarikatan Oelama tidak hanya ingin diizinkan untuk meluaskan cabangcabangnya di Jawa dan Madura, tetapi ke seluruh Indonesia. Ajuan tersebut dikabulkan oleh pemerintah Hindia Belanda dengan penetapan badan hukum pada 1937. ${ }^{89}$ Mulai saat itu, P.O. berhasil melebarkan sayapnya ke seluruh

\footnotetext{
${ }^{85}$ Ibid.

${ }^{86}$ Ibid., 110

${ }^{87}$ Lihat, Verslag van het congres van de Perserikatan Oelama te Madjalengka van 29-31 Augustus 1931. Batavia, 16 October 1931. ANRI, 1-11. Lihat pula, Wawan Hernawan Seabad, 110-111.

${ }^{88}$ Verslag van het 13de congres van de "Persjarikatan Oelama" in September 1935 te Indramajoe. Batavia, 23 September 1935. ANRI, 1-6.

${ }^{89}$ Algemeen Secretaris No. 43. Tanggal 18 Agustus 1937. ddo. Kiverson-Cipanas. ANRI.
}

Indonesia, sehingga mulai berdiri cabang-cabang P.O. di Semarang, Purwokerto (Banyumas), dan Tebing Tinggi..$^{90}$ Masih pada 1937, ketika dibentuk MIAI (Madjelis Islam A 'la Indonesia), Abdul Halim sebagai Hoofdbestuur P.O. masuk jajaran Hoofdbestuur MIAI. Amanah itu terus diembannya hingga beralih ke masa pemerintah Pendudukan Jepang. ${ }^{91}$

Pada 14-18 April 1938, P.B. P.O. menyelenggarakan Kongres ke-15 di Majalengka. Kongres P.O. ke-15 sering disebut "Kongres Dewasa". Kuat dugaan, hal itu disematkan karena pada usianya yang ke-21 organisasi pergerakan ini telah berhasil melahirkan regenerasi pimpinan. Pada kongres itu terpilih sebagai Voorzitter Hoofdbestuur, seorang tokoh muda dari Kuningan Ahmad Ambary. ${ }^{92}$ Ia dibantu oleh tokoh muda lainnya, masing-masing: Asjikin Hidajat sebagai Secretaris (Sekretaris) dan Abdoel Wahab sebagai Penningmeester (Bendahara). Sementara Abdul Halim didaulat sebagai Adviser (Penasehat) Persyarikatan Oelama. ${ }^{93}$

\section{Masa Pemerintah Pendudukan Jepang}

Setelah sebelumnya beberapa organisasi besar Islam di Indonesia sempat dibekukan oleh pemerintah Pendudukan Jepang, pada September 1943 empat organisasi besar, masingmasing: Moehammadijah, Nahdlatoel Oelama, Perikatan Oemmat Islam, ${ }^{94}$ dan Persatoean Oemmat Islam Indonesia, diizinkan melakukan kegiatannya kembali. Sementara MIAI (Madjelis Islam A'la Indonesia), karena kegiatannya

\footnotetext{
${ }^{90}$ Jalaluddin, 378.

${ }^{91}$ Djarnawi Hadikusuma, Dari Jamal al-Din al-Afghani sampai K.H.A. Dahlan. (Yogyakarta: Persatuan, t.th.), 87. Lihat pula, Anonimous. Panji Masyarakat II, no. 2 (1967): 19.

${ }^{92}$ Gunseikanbu, Orang Indonesia Jang terkemoeka di Djawa (T.tp.: Gunseikanbu, 2604), 432.

${ }^{93}$ Moh. Akim, 26. Lihat pula, Wawan Hernawan, Seabad, 114115 .

${ }^{94}$ Setelah Persjarikatan Oelama sempat fakum akibat dibekukan oleh pemerintah Pendudukan Jepang, atas ajuan Abdul Halim, Ahmad Ambary, dan Asjikin Hidajat pada awal 1943 organisasi P.O berganti nama menjadi Perikatan Oemmat Islam. Dengan perubahan ejaan Bahasa Indonesia pada 1947 (ejaan Soewandi) menjadi Perikatan Ummat Islam (PUI). Lihat, A. Darun Setiady, 252-253.
} 
dipandang kurang memuaskan pemerintah Pendudukan Jepang, kemudian dibubarkan pada Oktober 1943. Sebagai penggantinya, kemudian dibentuk Masjumi (Madjelis Sjoero Moeslimien Indonesia) yang disahkan oleh Gunseikan pada 22 November 1943. K.H. Hasjim Asj'ari dari NU (Nahdlatul Ulama) kemudian ditunjuk sebagai Ketua Umum untuk pertama kalinya. Melalui jabatannya itu, ia kemudian diangkat menjadi penasihat Gunseikan. Pada waktu yang hampir bersamaan, dalam badan-badan seperti: Cuo Sangi In, maupun Syu Sangi Kai sejumlah tokoh Muslim juga banyak yang terpilih menjadi anggota badan-badan itu. Selanjutnya, dalam Cuo Sangi In yang beranggotakan 43 orang, enam orang di antaranya berasal dari tokoh muslim. Di antaranya: Abdul Halim, Wachid Hasjim, dan Fathoerrohman. ${ }^{95}$ Pada masa-masa selanjutnya, Cuo Sangi In kemudian diubah menjadi Dokuritsu Junbii Chōsakai/ Dokuritsu junbi Cosakai. Badan ini dikenal dengan BPUPKI (Badan Penyelidik Usaha-Usaha Persiapan Kemerdekaan Indonesia). Dalam badan itu, Abdul Halim termasuk kelompok 62 bersama dengan Radjiman Wedyodiningrat. ${ }^{96}$ Sebuah sejarah yang tidak dapat diabaikan, karena BPUPKI merupakan "cetak biru" dalam pembentukan Dasar Negara RI dan UUD 1945, Perikatan Umat Islam (PUI) yang diwakili oleh Abdul Halim telah ikut memberikan sumbangan bagi perumusan kemerdekaan Indonesia. ${ }^{97}$

\section{Masa Indonesia Merdeka sampai Akhir Hayat}

Setelah Indonesia memproklamirkan kemerdekaannya pada 17 Agustus 1945, dijumpai sejumlah informasi, bahwa aktivitas Abdul Halim tidak berhenti sampai di sana. Pada September 1945, tercatat ia diangkat menjadi anggota KNID (Komite Nasional Indonesia Daerah)

\footnotetext{
${ }^{95}$ Marwati Djoened Poesponegoro dan Nugroho Notosusanto, Sejarah Nasional Indonesia, Jilid VI (Jakarta: Balai Pustaka, 1993), 26.

${ }^{96}$ Wawan Hernawan, Seabad, 118-119.

${ }^{97}$ Ibid., 120.
}

di Karesidenan Cirebon. ${ }^{98}$ Namun demikian, proklamasi kemerdekaan Indonesia tidak lantas mendapatkan pengakuan dari pemerintah Belanda. Mereka bahkan bermaksud menjadikan kembali wilayah Nusantara sebagai bagian dari kerajaan mereka. ${ }^{99}$ Hal itu ditunjukkan dengan adanya serangkaian agresi militer. Paling tidak, ada dua agresi yang dilancarkan mereka, yaitu: pertama, berlangsung pada Juli 1947 (Agresi Militer I), dan kedua, pada Desember 1948 (Agresi Militer II). ${ }^{100}$

Sebagai akibat dari agresi militer yang dilakukan oleh pemerintahan NICA (Nederland Indies Civil Administration), di Pulau Jawa terjadi evakuasi rakyat secara besar-besaran. Peristiwa tersebut menyebabkan rakyat harus berjuang secara gerilya. Dalam masa gerilya itulah, Abdul Halim diangkat menjadi "Bupati Masyarakat" Majalengka oleh Hamdani, yang ketika itu menjabat sebagai Residen Cirebon. ${ }^{101}$ Sebagai tanggung jawab atas amanah yang diembannya, Abdul Halim kemudian memimpin masyarakat Majalengka dalam perang gerilya di sekitar kaki gunung Ciremai dan menghadang pergerakan militer Belanda di wilayah Karesidenan Cirebon. ${ }^{102}$ Sebagai balasan, pihak militer Belanda menyerang Pasirayu, kediaman Abdul Halim, karena dianggap sebagai basis TNI dan lasykar PI (Hizbullah). Pada serangan itu, Abdul Halim, para putra, dan menantunya berhasil ditangkap dan diinterogasi pasukan Nefis. Dalam serangan itu sebagian bangunan di komplek Santi Asromo luluh-lantak. ${ }^{103}$ Namun demikian, Abdul Halim tetap pada pendiriannya untuk tidak melakukan politik kompromi dengan pasukan militer

\footnotetext{
${ }^{98}$ Sekretariat Jenderal Dewan Tanda-tanda Kehormatan RI. Profil Penerima Tanda Kehormatan Gelar Pahlawan Nasional, Bintang Mahaputera dan Bintang Budaya Parama Dharma dalam Rangka Peringatan Hari Pahlawan 10 November 2008 (Jakarta: Sekjen DT2K-RI, 2008), 24-25.

${ }^{99}$ Nina Herlina Lubis, et. al., Biografi Prof. K.H. Anwar Musaddad (Bandung: YMSI Cabang Jawa Barat, 2015), 15.

${ }^{100}$ Marwati Djoened Poesponegoro dan Nugroho Notosusanto, 392.

${ }^{101}$ Sekretariat Jenderal Dewan Tanda-tanda Kehormatan RI., 25.

${ }^{102}$ Ibid.

${ }^{103}$ Ibid., 26
} 
Belanda. Setelah dilepas, ia kemudian menjadi penyuplai logistik bagi TNI di daerahnya, sehingga sekalipun pasukan TNI dikepung oleh pasukan militer Belanda, mereka tidak kekurangan makanan. ${ }^{104}$

Agresi militer Belanda, pada perkembangannya ternyata tidak hanya fokus pada bidang militer, tetapi juga bidang agama dan politik. Dalam bidang agama, sebut saja misalnya, guna memecah-belah bangsa Indonesia yang baru terbentuk, mereka menyusun gerakan sparatis yang bersifat millenaristis. Hal itu seperti terjadi di Burujulwetan, Jatiwangi pada 1947 di bawah pimpinan Haji Sarip. ${ }^{105}$ Dalam ajarannya, Haji Sarip mengajak rakyat Majalengka untuk mendukung Belanda dalam mengembalikan kekuasaan di daerahnya. Ia menyatakan bahwa pada 12 Rajab akan terjadi pertempuran hebat dan semua orang yang salah akan kalah. Para leluhurnya akan membantu dalam peperangan itu, sehingga berdiri kembali pemerintahan baru. Namun, yang memerintah bukan lagi orang Belanda yang dahulu telah menjajah Indonesia, tetapi para leluhurnya yang menjelma menjadi orang Belanda. Oleh karena yang memerintah adalah para leluhurnya, maka Majalengka akan memperoleh kemakmuran. Namun, gerakan separatis Haji Sarip dapat dipatahkan, karena Abdul Halim selalu mengobarkan semangat kepada masyarakat untuk tetap mempertahankan NKRI. ${ }^{106}$

Sementara dalam bidang politik, pasukan militer Belanda berusaha menerapkan konsep negara federal. Untuk mencapai tujuannya, mulai didirikan beberapa negara bagian. Di Jawa Barat, misalnya, berdiri Negara Pasundan. Melihat kenyataan yang disebut terakhir, Abdul Halim bersama anggota Perikatan Ummat Islam (PUI) dan kaum muslim lainnya mendirikan gerakan tandingan, yaitu Gerakan Muslimin Indonesia

\footnotetext{
${ }^{104}$ Ibid.

${ }^{105}$ Ibid.

${ }^{106}$ Ibid.
}

(GMI) berpusat di Bandung. ${ }^{107}$ Ia sendiri sebagai Ketua Umum GMI. Sebagai Ketua Umum GMI, Abdul Halim kemudian diangkat menjadi Ketua Panitia Penggempuran Negara Pasundan ${ }^{108}$ Pada akhir Maret 1950, Negara Pasundan berhasil dibubarkan. ${ }^{109}$

Keputusan politik lainnya dari Abdul Halim yang tidak dapat diabaikan adalah penolakannya terhadap Daarul Islam (DI/TII) yang diproklamirkan S.M. Kartosoewirjo pada 1949. Ia kurang sepaham dengan Kartosoewirjo, karena dipandang banyak menyampaikan ajaran yang kurang sesuai dengan ajaran Islam yang ia pahami. Bagi Abdul Halim, apa yang dilakukan Kartosoewirjo dan pengikutnya merupakan kekeliruan yang tidak dapat ditoleransi. Namun demikian, ia memilih menghindar untuk berkonfrontasi langsung dengan Kartosoewirjo, sebaliknya ia memberikan informasi tentang keberadaan DI/TII kepada pasukan TNI apabila mereka berkunjung ke Pasirayu. ${ }^{110}$

Di tengah kondisi bangsa Indonesia yang masih mencari identitas, keputusan politik Abdul Halim yang tidak dapat diabaikan lainnya adalah melakukan deklarasi fusi (peleburan) antara organisasi Perikatan Ummat Islam (PUI) yang berpusat di Majalengka dengan Persatuan Ummat Islam Indonesia (PUII) yang berpusat di Sukabumi. Deklarasi fusi tersebut berlangsung pada 5-6 April 1952/9-10 Rajab 1371 di Bogor. ${ }^{111}$ Tujuan dilaksanakannya fusi agar perpecahan di kalangan kaum Muslim tidak semakin meluas dan mendalam. Hasil fusi menetapkan lahirnya organisasi massa Islam baru di Indonesia, yaitu Persatuan Ummat Islam (PUI) dengan kedudukan pusatnya untuk pertama kali di Bandung. Dalam keputusan sementara menunggu dilaksanakan

\footnotetext{
${ }^{107}$ Ibid., 27.

${ }^{108}$ Moh. Akim, 40.

${ }^{109}$ Marwati Djoened Poesponegoro dan Nugroho Notosusanto, 209.

${ }^{110}$ Lihat, Karl D. Jackson, Kewibawaan Tradisional, Islam, dan Pemberontakan Kasus Darul Islam Jawa Barat, terj. Pustaka Utama Grafiti (Jakarta: Grafiti, 1990), 18. Lihat pula, Sekretariat Jenderal Dewan Tanda-tanda Kehormatan RI., 28. ${ }^{111}$ Ibid.
} 
Muktamar, Abdul Halim menjadi Ketua Dewan Penasihat oraganisasi itu. ${ }^{12}$

Pada Pemilihan Umum legislatif dan konstituante 1955, Abdul Halim dari Persatuan Ummat Islam (PUI) terpilih menjadi anggota Konstituante dengan tugas pokok menyusun Undang-Undang Dasar yang kelak akan dijadikan pengganti UUD Sementara. ${ }^{113}$ Namun demikian, pada 1956 kesehatannya mulai terganggu, sehingga ia harus mengurangi aktivitasnya. Abdul Halim pun kemudian memilih tinggal di Santi Asromo, Pasirayu-Majalengka. ${ }^{14}$ Pada 1960 kesehatan Abdul Halim betul-betul semakin menurun. Di tengah sakitnya, ia masih sempat memberikan ceramah pada pengajian rutin mingguan di Santi Asromo. Dalam setiap pengajiannya, ia senatiasa mengulang-ulang pesan, "titip Santi Asromo dan PUI". ${ }^{15}$ Abdul Halim wafat hari Senin, 7 Mei 1962/3 Dzulhijjah 1381 sekitar pukul 15.05 WIB., dalam usia 75 tahun. Ia dimakamkan keesokan harinya di Kompleks Balai Pamulangan Pondok Mufidat Santi Asromo Pasirayu Majalengka. ${ }^{116}$

\section{Penghargaan dan Tanda Jasa}

Abdul Halim termasuk di antara tokoh nasional yang mendapat apresiasi pemerintah R.I. Sekretariat Jenderal Dewan Tanda-tanda Kehormatan RI., ${ }^{117}$ menyebutkan beberapa penghargaan dan tanda jasa yang disematkan kepada Abdul Halim. Pertama, tanda penghargaan sebagai Oelama Pejoeang dari Yayasan Asih Fatmah. Kedua, Abdul Halim juga termasuk di antara tokoh nasional yang mendapat anugerah Bintang Mahaputera Utama dari pemerintah Republik Indonesia dengan No. 048/TK/Tahun 1992. Ketiga, atas sejumlah pemikiran dan gerakan politik yang ditorehkan Abdul Halim,

\footnotetext{
${ }^{112}$ S. Wanta, Intisab, 33.

${ }^{113}$ Sekretariat Jenderal Dewan Tanda-tanda Kehormatan RI., 27.

${ }^{114}$ Ibid., 28-29.

${ }^{115} \mathrm{~S}$. Wanta, Intisab, 40.

${ }^{116}$ Ibid., 41. Lihat pula, Wawan Hernawan, Abdul Halim and His, 51.

${ }^{117}$ Sekretariat Jenderal Dewan Tanda-tanda Kehormatan RI., 31.
}

berdasarkan hasil sidang Badan Pembina Pahlawan Pusat pada 2008 dan hasil sidang Dewan Tanda-Tanda Kehormatan RI 30 Oktober 2008, serta Keputusan Presiden Nomor 041/TK/ TH. 2008 tertanggal 6 November 2008 Presiden menganugerahkan Gelar Pahlawan Nasional dan Bintang Mahaputera Adipradana.

\section{Kesimpulan}

Ide politik Abdul Halim tidak disusun dalam sebuah buku khusus, tetapi tersebar dalam sejumlah karya tulisnya. Pemikiran politik yang dikembangkannya mencerminkan tanggapan kritisnya atas kondisi kaum Muslim bumiputera yang terpuruk oleh ketidakadilan penguasa pada masanya. Tak pelak, Abdul Halim menjadi bagian penting dari spektrum sejarah politik di Indonesia dan kehadirannya telah memberi warna tersendiri dalam sejarah politik negeri ini. Ide politik Abdul Halim dimulai dari pemahamannya tentang rukun Islam. Baginya, rukun Islam merupakan fondasi politik dan kebangsaan bagi seluruh kaum Muslim. Pemikirannya tentang konsep al-salam, al-ishlah, santi asromo, santi lucu, dan intisab, menunjukkan konsistensinya untuk senantiasa berada dalam barisan tradisi politik kyai. Sementara itu, gerakan politik Abdul Halim yang diamini sejak masa pemerintahan Hindia Belanda, masa pemerintah Pendudukan Jepang, dan setelah Indonesia Merdeka sampai akhir hayatnya mencerminkan kuatnya otoritas politik seorang kyai dalam menghadapi tantangan zaman. Abdul Halim berhasil menunjukkan ketegasan sikap politiknya sebagai pewaris tradisi politik pesantren yang menghubungkan warisan keilmuan klasik dengan konteks zamannya. Kajian ini menunjukkan bahwa latar sosial-keagamaan dan perspektif seorang tokoh sangat berpengaruh terhadap sikap politik yang dikembangkannya, sehingga memungkinkan munculnya tradisi politik yang berbeda pula. Karena itu, mencermati dinamika pemikiran politik tidak dapat dilepaskan dari latar sosio-religious, ideologis, dan kepentingan politikus sendiri. 


\section{Daftar Kepustakaan}

A. Darun Setiady (ed.). Revitalisasi Peran PUI dalam Pemberdayaan Ummat. Bandung: PW PUI Jawa Barat, 2006.

Abduh. "Masyarakat Majalengka Wajib Membumikan Nilai Kepahlawanan KH Abdul Halim.” http://majalengka. cirebontrust.com/masyarakatmajalengka-wajib-membumikan-nilaikepahlawanan-kh-abdul-halim.html. Internet. Diakses pada 15 Oktober 2017.

Abdulchalim. Padoman Propaganda Persatoean Islam. Madjalengka: Hoofdbestuur Persjarikatan Oelama, 1928. KITLV.

- Padoman Persjarikatan Oelama. Madjalengka: Hoofdbestuur Persjarikatan Oelama, 1932. KITLV.

“Al-Qur'an wa al-'Ulum al-Asriyyah". Dalam Soeara Persjarikatan Oelama. Majalah IV, no. 5-6-7 (1932): 45.

-."Al-Qur'an wa al-'Ulum al-Asriyyah". Dalam Soeara Persjarikatan Oelama, Majalah IV, no. 8-9 (1932): 60-66.

Abdul Halim (Mohammad Sjatari). Pendaftaran Orang Indonesia jang Terkemoeka jang Ada di Djawa. Eks Arsip Gunseikanbu Cabang I, Pegangsaan Timur 36 Jakarta. Nomor A. 205 gol. III b. Nomor berkas A. 15, 2602/1942. ANRI.

Abdul Halim (ed.). Ketetapan Pengajaran di Sekolah Ibtidaiyyat Persjarikatan Oelama. Majalengka: Sederhana, 1934.

. Risalah Penoendjoek Bagi Sekalian Manoesia. Tasikmalaja: Galunggung Drukerij, 1938.

------. "Santi Asromo" dalam Brosur Santi Asromo. Majalengka: Santi Asromo, T.th.

. "Jalan Sempurna ke Arah Kebahagiaan Dunia Akhirat". Catatan Harian/
Manuskrip, T.th.

-------. "Kaum Muslimin Harus Insaf!" dalam As-Sjoero. Majalah VI, no. 5 (1935): 168.

Abu Sjahid Hidajat. "K.H. Abdul Halim Hidup dan Perjuangannya”. Panji Masyarakat 2, no. 2 (1967): 19-20.

Ahmad Djuwaeni. "Pengetahuan Mahasiswa terhadap Intisab dalam Hubungannya dengan Kesadaran Berorganisasi di Lingkungan Perguruan Tinggi PUI Suatu Kajian Empiris". Tesis S2 yang tidak diublikasikan. IAIN Syarif Hidayatullah, 1990.

. Arti dan Makna Intisab. Makalah. Jakarta: PB PUI, T.th.

Ahmad Faizin Karimi. Pemikiran dan Perilaku Politik Kiai Haji Ahmad Dahlan. Gresik: MUHIPress, 2012.

Algemeen Secretaris No. 43. Tangga 18 Agustus 1937. ddo. Kiverson-Cipanas. ANRI.

Anonimous. Panji Masyarakat II, no. 2 (1967): 19.

Azs. "PUI Usul BIJB Bernama Bandara KH Abdul Halim." http://www.radarcirebon. com/pui-usul-bijb-bernama-bandara-khabdul-halim.-html. Internet. Diakses pada 15 Oktober 2017.

Dartum Sukarsa. Potret K.H. Abdul Halim dalam Eksistensi Nasionalisme dan Perbaikan Umat (1887-1962). Bandung: Sarana Panca Karya Nusa, 2007.

Deliar Noer. Gerakan Modern Islam di Indonesia 1900-1942. Jakarta: LP3ES, 1995.

Departemen Pendidikan dan Kebudayaan. Pendidikan di Indonesia dari Zaman ke Zaman. Jakarta: Dewan Penelitian dan Pengembangan Pendidikan dan Kebudayaan, 1979.

Djarnawi Hadikusuma. Dari Jamal al-Din 
al-Afghani sampai K.H.A. Dahlan. Yogyakarta: Persatuan, T.th.

Djunaidi M. Mansur. "Penjelasan Maksud dan Tujuan Pendidikan PUI". Diktat. Majalengka: Tp, 1969.

End, Th. Van den. Sumber-sumber Zanding tentang Sejarah Gereja di Jawa Barat 1858-1963. Seri Sumber-sumber Sejarah Gereja di Indonesia No. 3. Jakarta: BPK Gunung Mulia, 1986.

Fawaid. "Bab II Konsep Idiologi Politik Perspektif Siyasah Syar'iyyah." http://digilib.uinsby. ac.id/968/5/Bab\%202.pdf. Internet. Diakses pada 29 Juli 2017.

Gunseikanbu. Orang Indonesia Jang terkemoeka di Djawa. T.tp.: Gunseikanbu, 2604. ANRI.

Jackson, Karl D. Kewibawaan Tradisional, Islam, dan Pemberontakan Kasus Darul Islam Jawa Barat. Terjemahan Pustaka Utama Grafiti. Jakarta: Grafiti, 1990.

Jalaluddin. "Santi Asromo K.H. Abdul Halim Studi tentang Pembaharuan Pendidikan Islam di Indonesia”. Disertasi S3 yang tidak diublikasikan, IAIN Syarif Hidayatullah, 1990.

Marwati Djoened Poesponegoro dan Nugroho Notosusanto. Sejarah Nasional Indonesia. Jilid VI. Jakarta: Balai Pustaka, 1993.

Moh. Akim. Kiai H. Abdul Halim Penggerak PUI. Majalengka: Yayasan K.H. Abdul Halim, 1964.

Nina Herlina Lubis. Metode Sejarah. Bandung: Satya Historika, 2008.

Nina Herlina Lubis, et al. Biografi Prof. K.H. Anwar Musaddad. Bandung: YMSI Cabang Jawa Barat, 2015.

Nursi, Bediuzzaman Said. Rahasia Kenikmatan Beribadah: Kisah dan Pesan Abadi yang Mengukuhkan Akidah dan Menggairahkan
Ibadah. Terjemahan Fauzi Bahreisy. T.tp.: Zaman\&Risale Press, 2012.

. Risalah Kebangkitan: Pengumpulan Makhluk di Padang Mahsyar. T.tp.: Risale Press, 2014.

S. Wanta. Intisab PUI Lahir Penjelasan dan Penerangannya. Majalengka: PB PUI Majelis Penyiaran Penerangan dan Dakwah, 1987.

-------. KH Abdul Halim dan Pergerakannya. Seri VI. Majalengka: PB PUI Majelis Penyiaran Penerangan dan Dakwah, 1991.

Sartono Kartodirdjo. Pemberontakan Petani Banten 1888 Kondisi, Jalan Peristiwa, dan Kelanjutannya. Jakarta: Pustaka Jaya, 1984.

Sekretariat Jenderal Dewan Tanda-tanda Kehormatan RI. Profil Penerima Tanda Kehormatan Gelar Pahlawan Nasional, Bintang Mahaputera dan Bintang Budaya Parama Dharma dalam Rangka Peringatan Hari Pahlawan 10 November 2008. Jakarta: Sekjen DT2K-RI, 2008.

Steenbrink, Karel A. Beberapa Aspek tentang Islam di Indonesia Abad ke-19. Jakarta: Bulan Bintang, 1984.

Sule. "Masjid Agung Al-Imam Usianya sudah 126 Tahun." Sule/Sinarmedia.com. Internet. Diakses, 6 September 2015.

Suwandi Wigena Prawira. "K.H. Abdul Halim dan Santi Asromo”. Dalam Panji Masyarakat, Majalah XVI, no. 177 (1975): 17-18.

Vahide, Sukran. Biografi Intelektual Bediuzzaman Said Nursi: Transpormasi Dinasti Usmani Menjadi Republik Turki, T.tp.: Risale Press, 2014.

Verslag van Het Congres van de Perserikatan Oelama te Madjalengka van 29-31 Augustus 1931. Batavia, 16 October 1931. ANRI. 
Verslag van het 13 de Congres van de "Persjarikatan Oelama” in September 1935 te Indramajoe. Batavia, 23 September 1935. ANRI.

Wawan Hernawan. Teologi K.H. Abdul Halim Ikhtiar Melacak Akar-akar Pemikiran Teologi Organisasi Massa Islam Persatuan Ummat Islam (PUI). Bandung: PW PUI Jawa Barat, 2007.

Seabad Persatuan Ummat Islam (19112011). Bandung: Yayasan Masyarakat Sejarawan Indonesia (YMSI) Cabang Jawa Barat dan Dewan Pimpinan Wilayah Persatuan Ummat Islam Jawa Barat bekerjasama dengan Divisi CSR Bank Jabar Banten (BJB) Pusat, 2014.

" 'Abdul Halim and His Movement (19111962): Seeking Historical Roots of Persatuan Ummat Islam(PUI) Movement". Dalam Internatinal Journal of Nusantara Islam 2, no. 1 (2014): 42-53.

Zulqarnain Hasan dan Muhammad Zaidi Abdul Rahman. Wanita sebagai Calon Pilihan Raya: Suatu Pembahasan dari Sudut Siyasah Syar'iyyah. Selangor Darul Ehsan: Yeohprinco SDN BHD, 2008. 